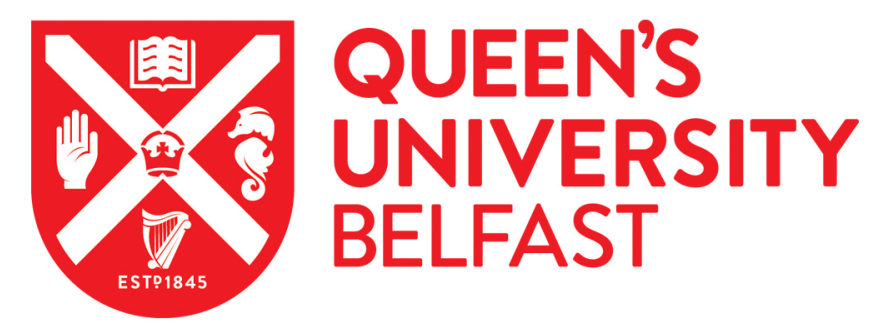

\title{
Standardization: Recent achievements of the IFCC Scientific Division
}

Gillery, P., \& Young, I. S. (2016). Standardization: Recent achievements of the IFCC Scientific Division. Clinica chimica acta; international journal of clinical chemistry. https://doi.org/10.1016/j.cca.2016.10.024

Published in:

Clinica chimica acta; international journal of clinical chemistry

Document Version:

Peer reviewed version

Queen's University Belfast - Research Portal:

Link to publication record in Queen's University Belfast Research Portal

\section{Publisher rights}

Copyright Elsevier 2016

This manuscript is made available under a Creative Commons Attribution-NonCommercial-NoDerivs License

(https://creativecommons.org/licenses/by-nc-nd/4.0/), which permits distribution and reproduction for non-commercial purposes, provided the author and source are cited.

\section{General rights}

Copyright for the publications made accessible via the Queen's University Belfast Research Portal is retained by the author(s) and / or other copyright owners and it is a condition of accessing these publications that users recognise and abide by the legal requirements associated with these rights.

Take down policy

The Research Portal is Queen's institutional repository that provides access to Queen's research output. Every effort has been made to ensure that content in the Research Portal does not infringe any person's rights, or applicable UK laws. If you discover content in the Research Portal that you believe breaches copyright or violates any law, please contact openaccess@qub.ac.uk. 


\section{Accepted Manuscript}

Standardization: Recent achievements of the IFCC Scientific Division

Phlippe Gillery, Ian S. Young

PII: $\quad$ S0009-8981(16)30433-8

DOI: $\quad$ doi: $10.1016 /$ j.cca.2016.10.024

Reference: $\quad$ CCA 14533

To appear in: $\quad$ Clinica Chimica Acta

Please cite this article as: Gillery Phlippe, Young Ian S., Standardization: Recent achievements of the IFCC Scientific Division, Clinica Chimica Acta (2016), doi: 10.1016/j.cca.2016.10.024

This is a PDF file of an unedited manuscript that has been accepted for publication. As a service to our customers we are providing this early version of the manuscript. The manuscript will undergo copyediting, typesetting, and review of the resulting proof before it is published in its final form. Please note that during the production process errors may be discovered which could affect the content, and all legal disclaimers that apply to the journal pertain. 


\section{Standardization : recent achievements of the IFCC Scientific Division}

Phlippe Gillery ${ }^{1,}$, Ian S. Young ${ }^{2}$.

1 - University Hospital of Reims, Laboratory of Pediatric Biology and Reseach, Reims, France

2 - The Centre for Public Health, Queen's University Belfast, Belfast, U.K.

* Corresponding author

For many years, the Scientific Division (SD) of the International Federation of Clinical Chemistry and Laboratory Medicine (IFCC) has been committed to developing reference measurement procedures (RMPs) and reference materials in order to improve standardization of laboratory assays and result interpretation on a global basis. These activities address the general goal of IFCC to advance the science of laboratory medicine worldwide, especially in areas of importance where immediate benefits to clinical outcomes may result $[1,2]$. In this issue, IFCC-SD reports important achievements of its committees (Cs) and working groups (WGs) over the last three years. Cs are theme-oriented, overseeing a range of projects within a focussed theme, whereas WGs are task-oriented, covering various fields of laboratory medicine. The list of active Cs and WGs in 2016 is shown in Table 1.

A pre-requisite and a major challenge for any scientific activity is the development of an agreed universal vocabulary and definitions. For many years, IFCC-SD has been involved in promoting the use of international nomenclature within laboratory medicine, through its connections with the International Union of Pure and Applied Chemistry (IUPAC) and the activities of their Joint Committee on Nomenclature, Properties and Units (C-NPU). A prominent output of these joint activities is the "Silver Book" [3]. This book describes the global scientific standards that summarize terminology in laboratory medicine. The current paper reports the first update of this book in a generation, and underlines the scientific background of this document and its relevance to biological nomenclature in the e-health era, especially as many laboratory medicine specialists are unaware of its existence.

Several measurands have been standardized by IFCC-SD over the course of the last few decades, providing robust anchors for the routine use of tests by manufacturers and clinical laboratories. This has permitted the better use of tests in public health, even though the 
consequences of standardization in terms of unit use and result expression in clinical practice have sometimes been unexpected, as in the case of $\mathrm{HbA}_{1 \mathrm{c}}$ [4]. Careful discussions with clinical societies and regulatory authorities are critical in order to avoid unanticipated adverse consequences of standardization activities.

A recent example is the standardization of thyroid function tests. The dedicated committee (C-STFT) has been very active in the past few years and has succeeded in standardization of free thyroxine (FT4) measurement and harmonization of thyroid stimulating hormone (TSH) assays. However, due to the substantial change of reported values for some assays following standardization, C-STFT was asked by the Food and Drug Administration (FDA) to develop a tool to assess the stability of the new calibration before implementation in the market and clinical laboratories. In the paper published here, C-STFT has used two webbased applications based on instrument-specific moving medians of outpatients results ("Percentile") and flagging rates ("Flagger") based on data from individual laboratories grouped by instrument or assay. They showed that both applications are suitable to document the stability of calibration in the post standardization phase, which is a major goal to ensure the long-term robustness of the system [5].

Another measurand successfully standardized during the last few years with significant impact on result expression is carbohydrate-deficient transferrin (CDT), a well-recognized marker of alcohol consumption. The paper published in this issue clearly describes the different steps of the standardization process : 1 - Definition of the measurand (serum disialotransferrin to total transferrin fraction as a percentage) ; 2 - Candidate reference method (well-defined HPLC method) ; 3 - Establishment of a network of reference laboratories for assigning target values to secondary CDT serum calibrators [6]. This process allows the direct comparison of values between methods using a common system of units, and provides an important added value for clinicians and patients, especially as this parameter is very important in a public health and medico-legal context in some countries.

Other measurands are making good progress towards standardization, such as $\mathrm{HbA}_{2} . \mathrm{HbA}_{2}$ is a key parameter for the diagnosis of $\beta$-thalassemia, which represents a healthcare burden in many parts of the world. Comparability of $\mathrm{HbA}_{2}$ values obtained by different methods is critical for the optimal use of absolute cut-off values which may be used for diagnostic purposes, which first required the establishment of a RMP. The manuscript published in this issue relates the different steps of $\mathrm{HbA}_{2}$ standardization, and illustrates the pitfalls and difficulties encountered during such as process [7]. This is a good example of the long and complicated journey which may be required to achieve a successful outcome in a 
standardization process, and illustrates the efforts of IFCC- SD to foster collaborations and synergies in order to obtain the desired results.

Another example of ongoing standardization is the 42 amino-acid form of amyloid $\beta$ (Aß1-42) in cerebrospinal fluid which has clinical and research utility as a biomarker for Alzheimer's disease. Although this peptide has been recognized as highly valuable for the diagnosis of Alzheimer's disease together with other markers like total and phosphorylated tau protein, commercially available immunoassays suffer from a lack of standardization which leads to uncertainly in result interpretation. The working group established by the IFCC-SD (WGCSF) has defined two candidate RMPs for the quantification of AB1-42 in CSF, based on liquid chromatography-tandem mass spectrometry. Both of them have been tested in ring trials where commutability studies have been performed, leading to the establishment of human CSF pools containing endogenous $A \beta 1-42$ at three concentrations as potential certified reference materials (CRMs). The next step will be the validation of a definitive RMP. This is thus an story in progress with important steps already accomplished which should lead in the near future to the standardization of this measurand [8].

Other tests already or not yet introduced into routine clinical practice need both preliminary analytical studies (validation of assays and harmonization of results) and clinical validation (demonstration by clinical studies of the clinical relevance of the assays).

This is the case for markers of bone turnover. In this field, IFCC has created a joint working group with the International Osteoporosis Foundation (IOF), with the objective of studying the possibilities for harmonization and clinical use of two bone markers, one marker of formation (serum procollagen type I N-propeptide) and one bone resorption marker (serum C-terminal telopeptide of type I collagen). The paper presented here shows that available data support the potential of these markers to be informative in relation to fracture risk and efficacy of osteoporosis treatment, provided harmonization of units for reporting values is achieved [9]. This provides a good example of collaboration of IFCC with a clinical society.

Another recent project of the Scientific Division is the standardization of parathyroid hormone (PTH) assays. PTH is used as a surrogate marker to assess skeletal and mineral disorders associated with chronic kidney disease and bone mineralisation defects. The paper published here underlines the clinical importance and the necessity of improving standardization of PTH immunoassays, and details the basis for the development of a RMP [10].

Autoimmunity is a complex domain recently addressed by the IFCC-SD through the establishment of the WG "Harmonization of Autoantibody Tests" (WG-HAT). Autoantibody 
testing is characterized by a striking lack of comparability of methods, mainly explained by the absence of common reference materials, whose availability could considerably improve the situation. In cooperation with the Institute for Reference Materials and Measurements (IRMM), WG-HAT has developed a CRM for myeloperoxidase-anti-neutrophil cytoplasmic antibodies (MPO-ANCA), usable as common calibrant and able to significantly improve the comparability of results from commercial immunoassays [11]. This first step will be followed by other developments on different antibodies.

The implementation of new analytical approaches in the clinical laboratory represents a recurrent challenge, even when such approaches are well established in the context of research or in specialist settings. The example of mass spectrometry is emblematic. This methodology has been restricted to the research area for many years, but recently the number of applications in the clinical laboratory has expanded considerably for small molecules and increasingly for peptides, and it is expected that such methods will become routine in the future. Therefore, the establishment of standardized procedures is of paramount importance. A review of methodological issues (selection and collection of samples, storage stability, preparation, analyte enrichment, trypsin digestion and quantification), as well as a review of the different analytical systems suitable for clinical mass spectrometry proteomics is provided by the SD-WG on Clinical Quantitative Mass Spectrometry Proteomics (WG-cMSP) [12]. This review clearly demonstrates that the control of pre-analytical and analytical phases is a major challenge for the development of reference methods and the diffusion of good practice in laboratories working routinely with mass spectrometry systems.

Another rapidly expanding field of interest covered by the SD is molecular diagnostics. After establishing a network of IFCC-approved reference laboratories, the Committee for Molecular Diagnostics (C-MD) has prepared an overview of various technical recommendations for the pre-examination phase of laboratory testing in molecular diagnostics, extensively referring to the International Organization for Standardization (ISO) guidance document ISO 15189. As this document is a general purpose document for laboratory medicine, C-MD has selected clinical vignettes illustrating how and why selected recommendations for the pre-examination phase might improve patient care for molecular diagnostic tests. These examples are drawn from various fields of molecular diagnostics including infectious diseases, oncology, inherited diseases and pharmacogenomics, and bring together experiences from various countries around the world, demonstrating the global nature of the issues [13]. 
Whatever the tests considered, the establishment of reference intervals is a major goal for laboratory medicine. In this regard, the Committee for Reference Intervals and Decision Limits (C-RIDL) of the SD has undertaken a global campaign in order to establish reference values for a series of common laboratory measurements. Two papers in this issue illustrate particular aspects of this multicentre study which has been conducted in 12 countries and has targeted 50 analytes. The first paper describes a novel statistical method which may be used for establishing reference values, utilising a robust and well-defined mathematical model. This study shows that reference intervals for nearly half of the analytes addressed showed significant between-country differences [14]. In the second paper, the sources of variation in reference values were explored for 13 ethnic groups from 12 countries. The major finding was that specific sex and age profiles of reference values were observed for the majority of analytes regardless of country. The close correlation between body mass index (BMI) and some reference intervals was notable. However, even though BMI-related changes in reference values were identified in all countries, the slope of regression line differred greatly across the ethnic groups, demonstrating the importance of taking into account several other independent parameters (geographical and ethnic origins, social context, lifestyle) when establishing reference intervals [15].

In conclusion, the manuscripts collected in this special issue highlight the continuous and successful efforts of IFCC-SD to achieve standardization or harmonization of laboratory tests and to ensure their optimal use in routine clinical laboratory practice. As the need for standardization of simple molecules is decreasing, IFCC-SD is committed to the standardization of more complex measurands, and will continue to have a leading role in this field, in conjunction with relevant partners, to ensure that laboratory medicine makes the most positive impact possible to patient care around the world. 


\section{$\underline{\text { References }}$}

[1] M. Panteghini, I.S. Young, P. Gillery. IFCC Scientific Division. Clin. Chem. Lab. Med. 48 (2010) 1529-1530.

[2] P. Gillery, I.S. Young. Progress towards standardization : an IFCC Scientific Division perspective. Clin. Chem. Lab. Med. 51 (2013) 915-918.

[3] R. Flatman, G. Férard, R. Dybkaer. Understanding the "Silver Book". An important reference for standardised nomenclature in clinical laboratory sciences. Clin. Chim. Acta 2016, doi:10.1016/j.cca.2016.06.035.

[4] P. Gillery, A. history of $\mathrm{HbA}_{1 \mathrm{c}}$ through Clinical Chemistry and Laboratory Medicine. Clin. Chem. Lab. Med. 51 (2013) 5-7.

[5] L.A. De Grande, K. Goossens, K. Van Uytfanghe, B. Das, F. MacKenzie, M.M. Patru, L.M. Thienpont. Monitoring the stability of the standardization of FT4 and TSH assays by use of daily outpatient medians and flagging frequencies. Clin. Chim. Acta 2016, doi:10.1016/j.cca.2016.04.032.

[6] H. Helander, J. Wielders, R. Anton, T. Arndt, V. Bianchi, J. Deenmamode, J.O. Jeppson, J.B. Whitfield, C. Weykamp, F. Schellenberg. Standardization and use of the alcohol biomarker carbohydrate-deficient transferrin. Clin. Chim. Acta 2016, doi:10.1016/j.cca.2016.05.016.

[7] R. Paleari, D. Caruso, P. Kaiser, C.G. Arsene, C. Schaeffer-Reiss, A. Van Dorsselaer, E. Bissé, M. Ospina, V.R. De Jesus, B. Wild, A. Mosca. Developing a reference system for the IFCC standardization of HbA2. Clin. Chim. Acta 2016, doi:10.1016/j.cca.2016.05.023.

[8] J. Kuhlmann, U. Andreasson, J. Pannee, M. Bjerke, E. Portelius, A. Leinenbach, T. Bittner, M. Korecka, R.G. Jenkins, H. Vanderstichele, E. Stoops, P. Lewczuk, L.M. Shaw, I. Zegers, H. Schimmel, H. Zetterberg, K. Blennow. CSF Aß1-42 - an excellent but complicated Alzheimer's biomarker - a route to standardization. Clin. Chim. Acta 2016,doi:10.1016/j.cca.2016.05.014.

[9] H.A. Morris, R. Eastell, N.R. Jorgesen, E. Cavalier, S. Vasikaran, S.A.P. Chubb, J.A. Kanis, C. Cooper, K. Makris. Clinical usefulness of bone turnover marker concentrations in osteoporosis. Clin. Chim. Acta 2016, doi:10.1016/j.cca.2016.06.036. 
[10] C.M. Sturgeon. Perspective and priorities for improvement of parathyroid hormone (PTH) measurement. A view from the IFCC working group for PTH. Clin. Chim. Acta 2016, accepted.

[11] E. Monogioudi, D.P. Hutu, G. Martos, J. Sheldon, H. Schimmel, P.L. Meroni, I. Zegers. Development of a certified reference material for myeloperoxidase-anti-neutrophil cytoplasmic auto-antibodies (MPO - ANCA). Clin. Chim. Acta 2016, doi:10.1016/j.cca.2016.05.031.

[12] S. Lehmann, C. Brede, P. Lescuyer, J.A. Cocho, J. Vialeret, P. Bros, V. Delatour, C. Hirtz. Clinical mass spectrometry proteomics (CMSP) for medical laboratory. Clin. Chim. Acta 2016, doi:10.1016/j.cca.2016.06.001.

[13] D.A. Payne, K. Baluchova, K.H. Peoc'h, R.H.N. van Schaik, K.C.A. Chan, M. Maekawa, C. Mamotte, G. Russomando, F. Rousseau. Pre-examination factors affecting molecular diagnostic test results and interpretation : a case-based approach. Clin Chim. Acta 2016, doi:10.1016/j.cca.2016.06.018.

[14] K. Ichihara, Y. Ozarda, J.H. Barth, G.Klee, L.Qiu, R. Erasmus, A. Borai, S. Evgina, T. Ashavaid, D. Khan, L. Schreier, R. Rolle, Y. Shimizu, S. Kimura, R. Kawano, D. Ambruster, K. Mori, B.K. Yadav. A global multicenter study on reference values: 1 Assessment of methods for derivation and comparison of reference intervals. Clin. Chim. Acta 2016, doi:10.1016/j.cca.2016.09.016.

[15] K. Ichihara, Y. Ozarda, J.H. Barth, G. Klee, B. Yadov, L. Xia, M. Hoffmann, F. Smit, A. Ruzhanskaya, S. Shak, D.N. Bustos, S. Kimura, M. Nagai, A. Takahashi. A global multicenter study on reference values: 2 - Exploration of sources of variation across the countries. Clin. Chim. Acta 2016, doi:10.1016/j.cca.2016.09.015. 
Committee on Nomenclature, Properties and Units (C-NPU)

R. Flatman (AU)

Committee on Molecular Diagnostics (C-MD)

D. Payne (US)

Committee on Reference Systems of Enzymes(C-RSE)

F. Ceriotti (IT)

Committee on Traceability in Laboratory Medicine (C-TLM)

L. Siekmann (DE)

Committee on Reference Intervals and Decision Limits (C-RIDL)

Y. Özarda (TR)

Committee on Standardization of Thyroid Function Tests (C-STFT)

L. Thienpont (BE)

Working group on Standardization of Hemoglobin $A_{2}\left(W G-H b A_{2}\right)$

R. Paleari (IT)

Working group on Standardization of Carbohydrate-Deficient Transferrin (WG-CDT)

J.P.M. Wielders (NL)

Working group on Standardization of Albumin Assays in Urine (WG-SAU)

L.M. Bachmann (US)

Working group on Pregnancy-Associated Plasma Protein A Standardization (WG-PAPPA)

Working group on Growth Hormone (WG-GH)

S. Wittfoot (UK)

Working group on Standardization of Insulin Assays (WG-SIA)

E. Lentjes (NL)

Working group on Standardization of Troponin I (WG-TNI)

M. Steffes (US)

Working group on Harmonization of Autoantibody Tests (WG-HAT)

D. Bunk (US)

Working group on Clinical Quantitative Mass Spectrometry Proteomics (WG-cMSP)

J. Sheldon (UK)

S. Lehmann (FR)

Working group on Parathyroid Hormone (WG-PTH)

C. Sturgeon (UK)

Working group on Cerebrospinal Fluid Proteins (WG-CSF)

K. Blennow (SE)

Working group on Standardization of Bone Markers Assays (WG-BMA)

H. Morris (AU)

Working group on Commutability (WG-CM)

G. Miller (US)

Table 1 Committees and Working Groups of the IFCC-SD in 2016 